\title{
WITCHCRAFT DENUNCIATIONS IN LATE IMPERIAL RUSSIA: PEASANT REACTIONS TO THE KOLDUN
}

\section{Daniel C. Ryan}

The majority of peasants in late nineteenth century Russia believed in the power of magic and its ability to affect their lives in both beneficial and harmful ways. An important aspect of this outlook was witchcraft, which can be defined as "the attribution of misfortune to occult human agency" (Thomas 1971: 436). Nearly any personal misfortune, including impotence, illness, death, crop failure, and the death of livestock, could be construed as an act of witchcraft, or "spoiling" (porcha). Peasants, however, could attempt to defend themselves against witchcraft by turning to magical practitioners who lived in and around their villages.

Interestingly, these same individuals whom peasants sought out for magical aid could also be suspected of witchcraft and were sometimes attacked for this supposed crime. Suspicions stemmed from the fact that peasants tended to regard some magical practitioners, such as the male sorcerer, or koldun, who will be discussed below, quite ambivalently. In fact, they were often believed to have the ability to spoil. Moreover, there is evidence that magical practitioners sometimes sought to intimidate their potential clientele through threats and ambiguous speech in order to underscore the importance of seeking out their help.

This study employs a variety of sources, including folklore, ethnographic studies, and reports of attacks against kolduny (plural of koldun) found in a variety of nineteenth century sources, in order to examine their vulnerable position within rural communities. The koldun's marginal social status, coupled with peasants' ambivalent attitude toward magical practitioners, made him an easy target for witchcraft denunciations and violence. The time frame of this study ranges from the 1860 s to the 1890 s - a period marked by a growth in élite interest in studying the peasantry, and increased instances of denunciations and violence against perceived witches (Worobec 1995: 167-168). The chronological end point for the study - the 1890s, is apt because attacks against suspected 
witches seem to have declined significantly by the end of the century (Krainski 1900, Levenstim 1897, Vesin 1892: 57-79) and these instances are the best gauge for measuring how marginal figures were treated in the community once denounced.

Kolduny, like other magical practitioners, were typically economically and socially marginal individuals. They were landless, elderly and poor (Ramer 1991: 214), but they had acquired a large body of magical, and sometimes herbal knowledge, and gained a reputation which could allow them to eke out an existence by performing a variety of services for other peasants.

Magical practitioners included healers (male znakhar', female znakharka), fortunetellers (male kudes'nik, female vorozheia) and sorcerers (male koldun, female koldun'ia). Peasants used these terms rather loosely, and often interchangeably. This stems partly from the fact that magical practitioners performed a variety of overlapping functions, and also due to regional or even personal variations. One primary difference between healers and sorcerers was the belief that sorcerers derived their powers from an "unclean force" (nechistaia sila), which might refer to the assistance of petty demons, or the "unclean" dead (those who had drowned, committed suicide, died unbaptized, or had practiced sorcery while living) (Ivanits1989: 97, 104). While a koldun might share similarities in function with a healer or a koldun'ia, one role that was specifically accorded to him was that of honored guest and protector of the peasant wedding.

An examination of the koldun in this single setting can help to illustrate the hazy boundaries between benevolent and malevolent magic, as well as to highlight a specifically male category of magical practitioners whom peasants denounced for specific acts of witchcraft. Although the koldun seemingly functioned as a protector of weddings, an analysis of peasant views indicates that the peasantry held this type of koldun in a much more ambivalent esteem. The wedding koldun provides a lucid example of how peasants could confuse magical practitioners for witches, even when they performed benevolent and prophylactic functions.

Once peasants came to believe that a fellow villager was behind their misfortunes, they sometimes decided to deal with him or her 
through violent means, sanctioned by the community. The decision to invoke popular justice (samosud) on a deviant or criminal element sometimes involved the consent of the village council (skhod), and could involve the participation, directly or indirectly, of the whole village. Otherwise a small group of peasants might take it upon themselves to rid a community of dangerous elements; the act nonetheless might be sanctioned by the community when its norms, well-being, or economic livelihood were threatened (Frank 1987: 239-265).

To understand how a "protector" koldun might incur the wrath of his fellow villagers, it is important to remember that peasants often feared, respected, and resented these imposing figures. For example, in 1887 the ethnographer A. Minkh recorded a memorate from two young men, aged 20-25, about the involvement of a koldun, Filat Semenov, in a wedding in Saratov province. During the wedding procession just before heading to church, the horses wouldn't move ahead and reared up (Minkh 1994: 285). Peasants considered such seemingly mild misfortunes as evidence of "spoiling" (Kuznetsova 1992: 125). Semenov approached the horses, and shouted "hey you - I myself am here!" (Ei vy - ia sam tut!), at which the horses started off at high speed. In this way, Semenov prevented a relatively small act of perceived spoiling. Semenov did not endear himself to his fellow villagers, and there is evidence to suggest that they considered taking action against him. At a later wedding he forced the guests to hug and kiss the posts supporting the awning outside of a peasant's hut. Minkh's informants stated that peasants in a meeting of the village assembly had discussed thrashing Semenov. Whether this anger stemmed from the cumulative effect of his threats and imposing stature, or this single indignation is not clear. The ethnographer's report does not say whether or not this was carried out, but this is still an important piece of evidence, though, because we see that the peasants did consider taking violent action against a koldun despite the fact that he had proved to be helpful in at least one instance.

Folk beliefs about the benefits of attacking witches and sorcerers were a widespread phenomenon in nineteenth century Russia as well as early modern Europe. For example, informants explained that if one were to strike Semenov's nose and if they wiped up the 
blood with a cloth and burned it, he would then lose the ability to practice magic (Minkh 1994: 285). Several other ethnographic sources also mention beliefs about striking a koldun in the mouth or nose to remove porcha and the ability to cause harm in the future (Maksimov 1994: 98, Nikitina 1994: 200, Popov 1903: 35-36). This phenomenon seems to be very similar to what Keith Thomas calls 'scratching' a witch. Thomas notes that in England peasants frequently committed minor acts of violence such as scratching or cutting a witch with knives, thorns, needles, and fingernails in order to draw blood. Peasants in Russia and England believed that to confront a purported witch in such a fashion could allow the bewitched to regain their health (Thomas 1971: 531, 544).

The customary activity of men in the role of the koldun left them wide-open to village-level suspicions and denunciations which could lead to such violent attacks. Such was the case when a koldun had been seated as the honored guest of a wedding in Penza guberniia in 1880. The bride's mother experienced a fit of so-called demonic possession (klikushi) which the peasants attributed to the koldun. Peasants in this case did not respond immediately, but the koldun's body was found the next morning in a mutilated condition (Iakushin 1896: 81-82).

More often, though, suspicions of spoiling led to denunciations, but not violence. Peasants had other available options for combating their perceived witch, besides the Russian variants of "scratching" kolduny. For example peasants might demand that a koldun lift a spell he purportedly cast, and sometimes they even paid for this service (Popov 1903: 29-30, Loginov 1993: 19, Vesin 1892: 72-73). A bewitched peasant could also seek help from another koldun, or other magical practitioners (Popov 1903: 26, Nikitina 1994: 197).

One possible reason why some kolduny were denounced and attacked for spoiling is that they may have made implicit threats by simply showing up to a wedding uninvited. Fabulates and memorates both detail such images as the vengeful koldun who spoils because peasants failed to turn to him. For example, S. Maksimov characterizes this aspect of folk beliefs rather melodramatically, writing that all stand in awe of the sorcerer who appears unexpectedly at the wedding feast. He writes of the koldun: "he is insulted, and will take revenge - late hospitality will not 
win him over now" (Maksimov 1994: 96). In fact, there is evidence to suggest that kolduny did resort to such intimidation in order to underscore their potential for wrath. The meaning which peasants may have ascribed to such a threat can be interpreted within the peasant's notion of a right to subsistence.

Because a koldun's unexpected arrival to a wedding could be interpreted as a threat of ill health, poor marital relations, impotence and similar afflictions, peasants might have understood it in terms of endangering an entire household's level of subsistence. To lose a family member to illness or death from spoiling would indeed be a personal loss, but it could also result in a loss of labor, and a reduction in the family's communal land-holding, which could lead to impoverishment. Furthermore, according to memorates and fabulates, marital strife or inter-family disputes (between the new daughter-in-law and her husband's family) arising from witchcraft could cause the daughter-in-law to return to her natal home (Kuznetsova 1992: 125, Popov 1903: 34). The prospect of such an occurrence would also be economically damaging for a household, whose laborers were its greatest resource. Although peasants could expect some kind of charity from their fellow villagers during times of economic difficulty, there were potentially long-term effects that accompanied a household economic crisis. Scott notes that impoverishment could force a family to sell off its resources, such as livestock, in order to meet short-term exigencies - a practice which jeopardized a household's future livelihood (Scott 1976: 3).

In this context, peasants who were confronted with an angry koldun at a wedding might display humility and hospitality with the hope of averting an act of spoiling. The painter of the Itinerant school, V. Maksimov (not to be confused with S. Maksimov, above), met with the self-described koldun, Grigori Semenovich Shabara (NovoLadozhsk uezd, Sankt Peterburg guberniia) who recounted one instance where he had not been invited to a wedding, but decided to make an appearance and walked in unannounced. Shabara claimed that the frightened family greeted him with bread and salt (a symbol of hospitality) and money so that he would not spoil the guests (Pomerantseva 1973: 143). In another case, a vorozhei came to a wedding uninvited, which led peasants to blame him for causing a woman's klikushestvo (Trudy komissii 1874: VI: 16). 
Shabara sought to impress others with his powers and claimed various acts, including mischief, as the result of his work. Among Shabara's boasts were that he set an illness upon his neighbor, found a stolen horse, spoiled a groom, and disgraced an elderly znakharka. Peasants regarded him with distrust, as can be seen from his account of a recent cholera epidemic which had barely left him unscathed. This fact led peasants of a neighboring village to believe that he was the cause of the outbreak. During this time he had spent three days at the home of an acquaintance in the village of Kazarev. A rumor began to spread that Shabara was responsible for the illness by having spoiled the wells in the village. This was reinforced by the fact that no one had died until he came to the village. He left during the evening of the third day in the village, and boarded a steamer to return home. At the final whistle, he saw a crowd gathering, which included several peasants bearing scythes. As the steamer pulled away, he heard several shouts, including "Shabara must be killed" (The information concerning Shabara and the cholera epidemic can be found in Popov 1903: 84-85). Apparently he barely escaped a violent instance of mob justice. While I found no sources containing peasant voices with which to corroborate this claim, Maksimov's driver displayed his unease in the presence of Shabara. He reportedly said, "this Grigorii Semenovich Shabara is a terrible koldun; you noticed that his horses started snorting (zachikhali), and went by quietly when he sat in the carriage?" (Pomerantseva 1973: 144).

Another koldun, Egor Gomozkov, similarly used his reputation to intimidate peasants who gathered for a wedding feast in Samara guberniia. Eventually, another villager killed Gomozkov in connection with his threats, though not exclusively this one. The peasant Tabunshchikov found him lying drunk in another neighbor's yard, and killed him; when the matter reached the criminal court, peasants provided authorities with testimony about a litany of misfortunes and threats they ascribed to him. For example, some villagers testified that indeed, Gomozkov was akoldun, noting that he caused them to fall ill, but that only he was able to restore their health. In court, the defendant remarked, "yes, justifiably I killed him because he was a koldun and spoiled people," and claimed to have committed the murder so that Gomozkov could no longer harm him or the village. The village priest stated that Gomozkov arrived 
uninvited to a wedding, demanding to be seated in the "first place" (Vesin 1892: 70-72).

The folklorists Boris and Iurii Sokolov witnessed another instance of posturing from a magical practitioner, the koldun Vasilii Veselov, from a village of Belozersk uezd, Novgorod guberniia, around 1915. $\mathrm{He}$ is described as a man of sixty years with a wrinkled brow, and an angry gaze. As for his reputation for witchcraft, the Sokolovs write, "everyone in the region in one voice calls him a koldun, whom they fear and respect." (Sokolov 1915: XLIV). He was purported to have thick books by which he told fortunes and practiced magic. Like other magical practitioners, Veselov similarly sought to impress upon others the potential misfortunes that awaited them. The Sokolovs noted that Vasilii Veselov uttered ambiguous threats, including one to them, "hey young man, you are going to (such and such) a village, but will you come back?" And in the presence of the Sokolovs, he said to a peasant, "hey, sonny [svat], why don't you come to see me? Or isn't life dear to you?" (Sokolov 1915: XVIV). While Veselov may have uttered these ambiguous statements hoping to impress others, and to suggest that they should come to see him for knowledge about the future, these same oblique statements could also be interpreted as personal threats. Although the Sokolovs' account does not include any information about denunciations or retaliations against Veselov for perceived acts of spoiling, his comportment probably did lead to resentment and hostility.

The figure of the koldun illustrates the important social roles which magical practitioners played in the peasant village, and demonstrates the vulnerability of such persons to suspicions of witchcraft and violent attacks. The koldun was a figure routinely denounced and sometimes attacked for the perception that he caused harm.

While I have examined the ambiguous perceptions of the male koldun within this paper, I do not wish to obscure the fact that magical practitioners in general could fall suspect in peasant denunciations of spoiling. Worobec notes that, "in a very narrow sense, the male or female healer in the Ukrainian or Russian village could easily be targeted as a witch," (Worobec 1995: 169). Unfortunately, though she acknowledges this possibility, she tends to overlook its 
importance. For example, when discussing the burning of a witch in Novgorodguberniia, she notes that the victim,Agrafena Ignateva, was a beggar who fell suspect after misfortune struck a family which had just refused to give her some cottage cheese (Worobec 1995: 183). While peasants searched their memories for any events which could help them determine who might have a grudge against them, another significant factor which could help to explain why suspicion fell on Ignateva is that she practiced magic, and was known as a koldun'ia (Krainski 1900: 77-78, Frank 1987: 133-134). After several recent misfortunes were ascribed to her, the village council decided to solve the matter. They sealed Ignateva's hut with her inside, and lit it on fire after surrounding it with hay. This event was witnessed by approximately two hundred persons (Vesin 1892: 64-65).

Like the koldun, female practitioners of magic seems to have made overt threats to their fellow villagers. For example, in Penza guberniia in 1879, a land-owner found the corpse of the reputed koldun'ia Anna Merzliakova near his hemp fields. When a formal investigation began, the peasant responsible admitted his guilt, but claimed to have been threatened, and indeed spoiled by Merzliakova. After she made a threat to harm him, the peasant was unable to urinate - and suffered for several days. Upon another encounter, she threatened him again, and he set upon her, striking her in the face until she collapsed (Vesin 1892: 67-68).

A peasant's account from Orel guberniia demonstrates similar threats by a peasant claiming to have magical powers. A peasant woman named Tat'iana had, during the course of an argument, threatened to spoil another woman by turning her into a dog. Others ran up hearing the commotion, and she threatened to turn them into dogs as well, at which one peasant struck her in the head. Her husband heard the commotion, and ran up to see what was going on, and was also beaten by the small crowd. They tied Tat'iana up and put her in the local jail, while threatening her husband that she would be exiled unless he bought them a bucket of vodka (Maksimov 1994: 117-118). While threatening other peasants could be an avenue for marginal community members to assert themselves, such behavior could also invite violent retaliation, as was the case with kolduny in late nineteenth century Russia. 
The koldun who appeared at peasant weddings is a good example of males whose activities made them vulnerable to being denounced and attacked for perceived acts of witchcraft. Kolduny, as well as other magical practitioners, were a relatively open target for witchcraft denunciations due to their reputations for spoiling, and their often abrasive comportment. Furthermore, their marginal status as relative outsiders in the village left them open to violence. They could not hope to have success affecting village opinion once denounced, because they lacked valuable social and economic influence which came from participation in the village assembly, for which landowning was a prerequisite. Peasants resented kolduny for their financial demands, extortion and begging, which could push a family closer to or below the subsistence level. While threats and intimidation may have been successful in the short run, ultimately they further isolated the koldun from village life due to the hostility they engendered among peasants.

\section{References}

Frank, S. 1987. Popular Justice, Community and Culture among the Russian Peasantry, 1870-1900. Russian Review, 46, pp. 239265.

Iakushin, E. 1896. Obychnoe Pravo. Materialy dlia bibliografii obychnago pravo, Vol. 2. Iaroslavl, pp. 81-82.

Ivanits, L. 1989. Russian Folk Belief. New York.

Krainski, N. 1900. Porcha, klikushi, i besnovatye kak iavlenia russkoi narodnoi zhizni. Novgorod.

Kuznetsova, V. 1992. O funktsiiakh kolduna v russkom svadebnom obriade Zaonezhie. Zaonezhie. Petrozavodsk, pp. 117-131.

Levenstim, A. 1897. Sueverie i ugolovnoe pravo. St. Petersburg.

Loginov, K. 1993. Semeinye obriady i verovania russkikh Zaonezhia. Petrozavodsk.

Maksimov, A. 1994. Nechistaia, nevedomaia i krestnaia sila. St. Petersburg.

Minkh, A. 1994. Narodnye obychai, obriady, sueveria i predrassudki krest'ian Saratovskoi gubernii. Sobrany v 1861-1888 gg. Russkoe koldovstvo, znakharstvo, vedovstvo. St. Petersburg, pp. 282-288.

Nikitina, N. 1994. K voprosu o russkikh koldunakh. Russkoe koldovstvo, znakharstvo, vedovstvo. St. Petersburg, pp. 172-205. 
Pomerantseva, E. 1973. Khudozhnik i koldun. Sovetskaia Etnografia, No. 2, pp. 137-145.

Popov, T. 1903. Russkaia narodno-bytovaia meditsina. St. Petersburg.

Ramer, S. 1991. Traditional Healers and Peasant Culture 18611917. Peasant Economy, Culture and Customary Law of European Russia. Princeton, pp. 207-232.

Scott, J. A. 1976. The Moral Economy of the Peasant. Rebellion and Subsistence in Southeast Asia. New Haven.

Sokolov, I. \& B. 1915. Skazki i pesni Belozerskogo kraia. Moscow.

Thomas, K. 1971. Religion and the Decline of Magic. New York.

Trudy komissii 1874. Trudy komissii po preobrazovaniu volostnykh sudov, Vol. 6. St. Petersburg.

Vesin, L. 1892. Narodnyi samosud nad koldunami. K istorii narodnykh obychaev. Severnyi Vestnik, No. 9.

Worobec, C. 1995. Witchcraft Beliefs and Practices in Prerevolutionary Russian and Ukrainian Villages. Russian Review, 54, No. 2, pp. 165-187. 